\title{
New Phylogenetic Molecular Markers in Bacteria of the Genus Bacillus: Fibrinolytic Proteases
}

\author{
Nguimbi Etienne ${ }^{1,2,3, \text { *, Soloka Mabika Faly Armel }}{ }^{1,2,3}$, Dibangou Valentin ${ }^{1}$, \\ Nzaou Stech Anomène Eckzechel, ${ }^{1,2}$, Kayath Aimé Christian ${ }^{1,3}$, Moyen Rachel ${ }^{1,2}$ \\ ${ }^{1}$ Laboratory of Cell and Molecular Biology, Faculty of Sciences and Techniques, Marien Ngouabi University, Brazzaville, Republic of Congo \\ ${ }^{2}$ Unit of Molecular Microbiology and Bioinformatics, Faculty of Science and Technology, Marien Ngouabi University, Brazzaville, Republic \\ of Congo \\ ${ }^{3}$ National Institute of Research in Exact and Natural Sciences (IRSEN), Avenue de l'Auberge Gascogne Scientific City (Ex. OROSTOM), \\ Brazzaville, Republic of Congo
}

\section{Email address: \\ etienne.ng1612@gmail.com (N. Etienne) \\ ${ }^{*}$ Corresponding author}

\section{To cite this article:}

Nguimbi Etienne, Soloka Mabika Faly Armel, Dibangou Valentin, Nzaou Stech Anomène Eckzechel, Kayath Aimé Christian, Moyen Rachel. New Phylogenetic Molecular Markers in Bacteria of the Genus Bacillus: Fibrinolytic Proteases. International Journal of Microbiology and Biotechnology. Vol. 6, No. 3, 2021, pp. 86-94. doi: 10.11648/j.ijmb.20210603.14

Received: February 16, 2021; Accepted: March 16, 2021; Published: August 18, 2021

\begin{abstract}
The fibrinolytic proteases developed by bacteria have become substances of medical interest, as they have been recognized as antithrombotic substances in the blood. It is in this context that a study has been carried out with the aim of studying the fibrinolytic proteases produced by bacteria isolated from food in the Congo. Four strains of bacteria of the genus Bacillus isolated from crushed and cooked squash seeds, namely Bacillus sp strain ASM7, Bacillus sp strain CRK, Bacillus pumilus strain ASM5, Bacillus subtilis strain ASM1, identified by their rDNA16S, were tested positive for the production of fibrinolytic proteases. The fibrin box technique was used. The diameters on the fibrin boxes prove a significant production of fibrinolytic proteases. The genes coding for these fibrinolytic proteases were amplified by PCR and 1\% Agarose gel electrophoresis shows that the size of the amplicons for the four strains is between $1200-1450 \mathrm{bp}$. The sequences of these coding genes have been for the four strains studied submitted to GenBank and the assigned accession numbers are respectively: Bacillus sp strain ASM7 MT743004, Bacillus sp strain CRK MT743005, Bacillus pumilus strain ASM5 MT743006, Bacillus subtilis strain ASM1 MT743007. These genes show a high degree of similarity of almost $99.50 \%$ with their counterparts in the databases, are all coding and show some observable differences. The translation of these genes in coherent reading frames confirms the amino acids already known in the active sites relating to their fibrinolysis role. The fibrinolytic protease CFE1 ( $\mathrm{Id}=\mathrm{QNJ60181)}$ is for Bacillus sp strain ASM7, the fibrinolytic protease CFE2 (Id=QNJ60182) is for Bacillus sp strain CRK, the fibrinolytic protease CFE3 ( $\mathrm{Id}=\mathrm{QNJ60183)}$ is for Bacillus pumilus strain ASM5, the fibrinolytic protease CFE4 ( $\mathrm{Id}=\mathrm{QNJ60184})$ is for Bacillus subtilis strain ASM1. All these fibrinolytic proteases show a strong similarity (99.51-99.76\%) with the Bacillus AprX serine protease, reference sequence. The phylogenetic inference test based on these fibrinolytic proteases shows that these proteases form a highly conserved characteristic group in bacteria of the genus Bacillus. This allowed us to retain these fibrinolytic proteases as an important phylogenetic molecular marker.
\end{abstract}

Keywords: Fibrinolytic Proteases, Sequencing, Phylogenetic Molecular Markers, Bacillus

\section{Introduction}

Proteolytic enzymes are ubiquitous in all living organisms and are essential for cell growth and differentiation. Extracellular proteases have commercial value and have multiple applications in different industrial sectors. Although there are many microbial sources available to produce proteases. But among all the contenders for the production of microorganisms, the genus Bacillus is unanimously recognised as a potential commercial producer [1]. Fibrin, responsible for 
blood coagulation, is activated after fibrinogen degradation by thrombin, and can be lysed (fibrinolysis) by plasmin [2, 3]. Normally, fibrin formation and fibrinolysis are kept in equilibrium [4, 5], however, an unbalanced situation occurs when fibrin cannot be hydrolyzed and can cause cardiovascular diseases, such as thrombosis, due to the accumulation of fibrin in the blood vessels [6].

Intravenous administration of urokinase and streptokinase has been widely used for thrombosis, but these enzymes have low fibrin specificity and are expensive. T-PA (tissue plasminogen activator) has been developed for the treatment of thrombosis because of its efficacy and greater affinity for fibrin [7, 5]. However, to prevent thrombosis and other related diseases, daily consumption of fibrinolytic enzymes from dietary sources is increasingly recommended. Many fermented foods offer such fibrinolytic activity, including examples such as the Korean Chungkook-Jang food [6, 4], the Chinese Duchi [8], Japanese natto [9], Japanese shiokara [10], Korean Doen-Jang [11], Asian fermented shrimp paste [12] and Indonesian tempeh [13], fermented cassava leaves: Ntobambodi in Congo [14].

It has been confirmed that nattokinase (NK) can directly lyse thrombi in vivo and that its oral administration can improve the activated plasma fibrinolytic effects as well as the production of t-PA [15].

The presence of strains producing fibrinolytic proteases in squash seeds crushed, packaged on leaves and cooked for consumption was first proven in Brazzaville in the study by [16] These strains of bacteria of the genus Bacillus were identified at the molecular level by their 16S rDNA and their phylogenetic classification based on this gene was tested [16].

In this work, four (4) strains of bacteria of the Bacillus genus already identified by their r16S rDNA were explored for their production of fibrinolytic proteases. These strains are respectively: Bacillus sp strain ASM7, Bacillus sp strain CRK, Bacillus pumilus strain ASM5 MK207435.1, Bacillus subtilis strain ASM1 MK193815.1. PCR amplification and sequencing of the genes coding for these enzymes have been carried out. Bioinformatics analysis made it possible to assess the degree of similarity between the different genes and the translation of these genes was carried out by SMS-ORF Finder-NCBI. The fibrinolytic protease sequences obtained were used not only to elucidate some properties, but also for a phylogenetic classification test to verify their role as a reference phylogenetic molecular marker in bacteria of the Bacillus genus.

\section{Materials and Methods}

\subsection{Bacterial Strains and Culture Conditions}

Four (4) Bacillus strains namely Bacillus sp strain ASM7, Bacillus sp strain CRK, Bacillus pumillus strain ASM5, Bacillus subtilis strain ASM1. Isolated from squash.

The study of the growth of the different strains was carried out in $250 \mathrm{ml}$ Erlenmeyers containing $100 \mathrm{ml}$ of medium (LB). A colony was inoculated. Incubation was carried out at $37^{\circ} \mathrm{C}$ for 48 hours. For each strain, $3 \mathrm{ml}$ of the bacterial suspension are taken under sterile conditions. $2 \mathrm{ml}$ will be used to measure the optical density of the cell culture at 600 nm using a zuzi type spectrophotometer (Model 4211/50) [17, $14,18]$.

\subsection{Fibrinolytic Proteases ASSAY}

Fibrinolytic activity was determined by the Fibrin Box method with modification [19]. The supernatant of the appropriate growth stage of Bacillus cells was used. Succinctly; $25 \mathrm{ml}$ of a $0.5 \%$ fibrin solution was mixed with $25 \mathrm{ml}$ of $1 \%$ agarose gel in a Petri dish and placed for 30 minutes at room temperature. Wells were made on the gel contained in the fibrin plate. 20 microliters of sample were added to each well and the plate was incubated at $37^{\circ} \mathrm{C}$ for 16 hours. The fibrinolytic activity was measured by the lytic surface through the diameter of the clear zone. The diameter of the clear zone was measured and used to assess enzyme production [14, 20, 18].

\subsection{PCR Amplification of Genes Encoding Fibrinolytic Proteases}

\subsubsection{Primers Design}

We have consulted the primers in the literature on fibrinolytic enzymes, many primers are used. In our previous study [21] an optimization on the primers used and the hybridization temperature for the amplification of genes coding for enzymes or fibrinolytic proteases was made, the results showed a variability at the level of the different strains. In fact, the fibrinolytic enzymes have a zone at the Nterminal end whose amino acids are highly conserved, this zone would be ideal for the choice of primers. This shows that degenerated primers are used to amplify the genes coding for fibrinolytic proteases in bacteria of the Bacillus genus, which illustrates the variability due to genetic mutations in this zone. However, in order to have a complete gene, it is necessary to take one of the F primers upstream. Given the diversity of genes encoding fibrinolytic enzymes, an in silico analysis was carried out in order to select a few primers. Data from the NCBI (National Center of Biotechnology Information) combined with those obtained with BLASTn shed light on the choice of primers. However, the test carried out with the Bacillus primers of [22], optimising the Hybridization temperature gave interesting results. These primers selected were: F5'CATATGTTTGGGTACTCTATGG-3' and R5'GGATCCTTATTGGCCGGGAACGGAA-3'. These primers were synthesized by the Society Macrogene France.

\subsubsection{Reaction mixture and PCR Conditions}

PCR was carried out according to the literature [22], but modified. The mixture was prepared in a total volume of 50 $\mu 1$ containing $31 \mu \mathrm{L}$ sterile distilled water, $20 \mathrm{ng}$ DNA $(2 \mu \mathrm{l})$, $200 \mathrm{nmol} / \mathrm{L}$ of each primer $(2 \mu \mathrm{l}), 0.2 \mathrm{mmol} / \mathrm{L}$ Dntp $(1 \mu \mathrm{l})$, $1.5 \mathrm{mmol} / \mathrm{L}_{\mathrm{MgCl}_{2}}(1 \mu \mathrm{l}), 10 \mu \mathrm{L}$ of one Taq polymerase enzyme buffer and $2.5 \mathrm{U}$ Taq $(1 \mu \mathrm{l})$.

A first denaturation at $95^{\circ} \mathrm{C}$ for 5 min. 35 cycles each comprising: denaturation at $95^{\circ} \mathrm{C}$ for $30 \mathrm{sec}$., hybridization at 
$65^{\circ} \mathrm{C}$ for $30 \mathrm{sec}$. and elongation at $72^{\circ} \mathrm{C}$ for one minute. And finally a final synthesis at $72^{\circ} \mathrm{C}$ for 7 minutes.

\subsection{Agarose Gel Electrophoresis of PCR Products}

\subsubsection{Gel preparation and Sample Processing}

\section{(i) Gel Preparation}

In a $250 \mathrm{ml}$ Erlenmeyer flask, we suspended $1 \mathrm{~g}$ of agarose in $100 \mathrm{ml}$ of TBE buffer (Tris $89 \mathrm{mM}$, Boric Acid $89 \mathrm{mM}$, EDTA $2.5 \mathrm{mM}$ and pH8.3), then heated until the agarose was completely dissolved, then allowed to cool to a temperature of 50 to $60^{\circ} \mathrm{C}$. After placing the comb in the mould, the gel was poured evenly into the mould and we waited until the gel polymerized. The comb was removed from the gel and the wells formed and then the gel was placed in the electrophoresis cell so that the gel wells were on the cathode side (as the DNA is negatively charged, migration will occur from the cathode to the anode). The cell has been previously filled with TBE buffer solution so that the gel is completely immersed in the buffer. DNA samples are deposited in an agarose gel immersed in a TBE buffer $(\mathrm{pH})$ and allowed to migrate under the effect of an electric field (DNA is a poly anion). The DNA is visualized by adding midori (a DNA dye which fluoresces by intercalating between the DNA bases). The speed depends on the size of the DNA molecule. A size marker is used to determine the size of the fragments.

\section{(ii) Sample Processing}

The DNA samples were processed before they were deposited in the wells. For this, we used 5microliters of DNA, 0.5 microliters of Midori and one microliters of Buffer Dye. Midori is an intercalating agent, it intercalates between the nucleotides and allows the nucleotides to fluoresce and the Buffer Dye (charge buffer), allows the DNA to be deposited and maintained at the bottom of the wells. The $6.5 \mathrm{ml}$ mixture is deposited in each well of the Gel.

\subsubsection{Migration in TBE Buffer and gel Visualization}

The gel was subjected to a voltage of $100 \mathrm{~V}$ for one hour, and we allowed it to migrate so that the blue line reached the end of the gel, then the power supply was interrupted. The gel was visualised under a UV lamp, by fluorescence.

\subsection{Sequencing of PCR Products}

The products of PCR amplification of the genes encoding fibrinolytic enzymes were purified using the NucleoFast 96 PCR plate (Macherey-Nagel EURL, France) and sequenced using BigDye terminator chemistry on an ABI3730 sequencer (Applied Biosystems, Foster City, California, USA). Sequencing was performed by electrophoresis on a 3730xl-Titania DNA analyser (Applied Biosystems) using the same primers. [16].

\subsection{Bioinformatic Analysis of the Obtained Sequences}

The resulting sequences were assembled using Codon Code Aligner and DNA Baser assembler software. The insilico analysis was carried out using BLAST (Basic Local
Alignment Search Tool (http://www.ncbi.nlm.nih.gov), from the NCBI (National Center for Biotechnology Information, Los Alamos). USA. The BLAST program uses the algorithm developed by [23] which is an algorithm used by a family of five programs that allow the alignment of a new sequence with respect to a database. To search for similar segments between a query sequence (or "query" sequence) and all the sequences present in the nucleic or protein bank. For BLAST, the similarity rate, E. value and score are determining parameters for homology [24].

We first used BLASTn to search for homologues to align with the obtained nucleotide sequences and we used the BioEdith program for the alignment of nucleotide and protein sequences.

SMS-ORF- finder from NCBI was used for the translation in different reading frames of the coding genes. Phylogenetic inference was done by MEGA 7 using the Neighbor-Joining method with coordination of Bootstrap values. Some sequences were put into GenBank and accession numbers were assigned.

\section{Results}

\subsection{Fibrinolytic Enzymes Production}

The Figure1 below shows the fibrinolytic activity of the four strains isolated from squashes. You can see the difference in their diameters. All the studied strains produce fibrinolytic enzyme. If the halo diameter is more important in the strains Bacillus subtilis ASM1, in The Bacillus subtilis sp. ASM7 and in the Bacillus pumilusASM5, the halo is smaller than in the first, the smaller dimeter is in the Bacillus sp CRK.

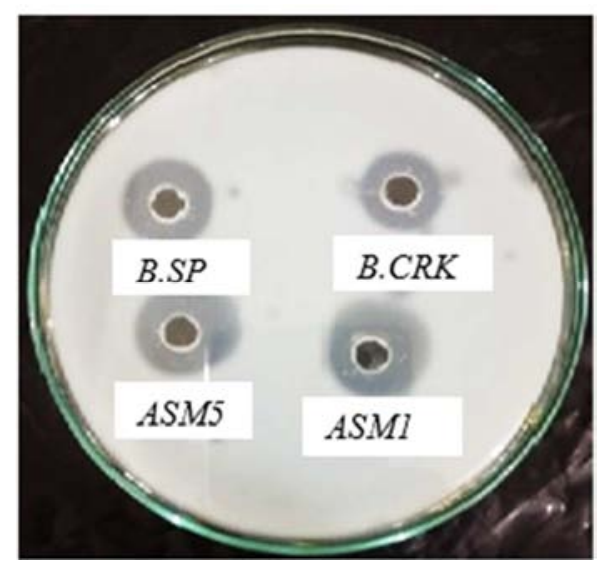

Figure 1. Halos representing the fibrinolytic activity of the four strains.

ASM5=Bacillus pumilus, ASM1=Bacillus subtilis, B. SP=Bacillus sp ASM7, B. $C R K=$ Bacillus $s p$ CRK

\subsection{PCR Amplification of Encoding Fibrinolytic Enzymes Genes}

Figure 2 shows 1\% agarose gel electrophoresis of PCR products of genes encoding fibrinolytic enzymes in isolated strains of squashes, profile displays bands of about $1200 \mathrm{bp}$ in all for strains. 


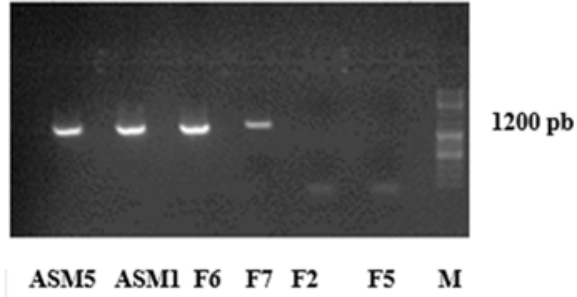

Figure 2. 1\% agarose gel Electrophoresis on of the PCR products of the genes encoding the fibrinolytic enzymes in Bacillus strains isolated from squashes.

$\mathrm{M}=$ Molecular weight marker, ASM5=Bacillus pumilus, ASM1=Bacillus subtilis, F6=Bacillus sp ASM7, F7=Bacillus sp CRK, F2=Bacillus sp, $F 5=$ Bacillus $s p$

Only four (4) strains were positive. The amplicons obtained after amplification of the 4 strains each showed a clear band of approximately $1200 \mathrm{bp}$ in size. The other strains of the negative controls obviously did not present bands.

\subsection{Bioinformatic Analysis of the Nucleic Sequences}

\subsubsection{Multiple Alignment of Nucleic Sequences Encoding for the Fibrinolytic Proteases}

Figure 3 on the multiple alignment of the different nucleotide sequences of the genes encoding the fibrinolytic enzymes of strains of bacteria of the genus Bacillus isolated from squashes, shows that there are areas where the nucleotides have been strongly conserved. However, some areas are less similar. Indels (insertion-deletions) can be observed in the areas of the following nucleotide positions: 118-119, where two types of sequences can be observed, one with two indels and the other with: AG. Nucleotide positions 167-171 with 5 indels on the one hand and TCTTT on the other hand; Nucleotide positions 212-218 with 7 indels on the one hand and on the other hand TGGCTGG

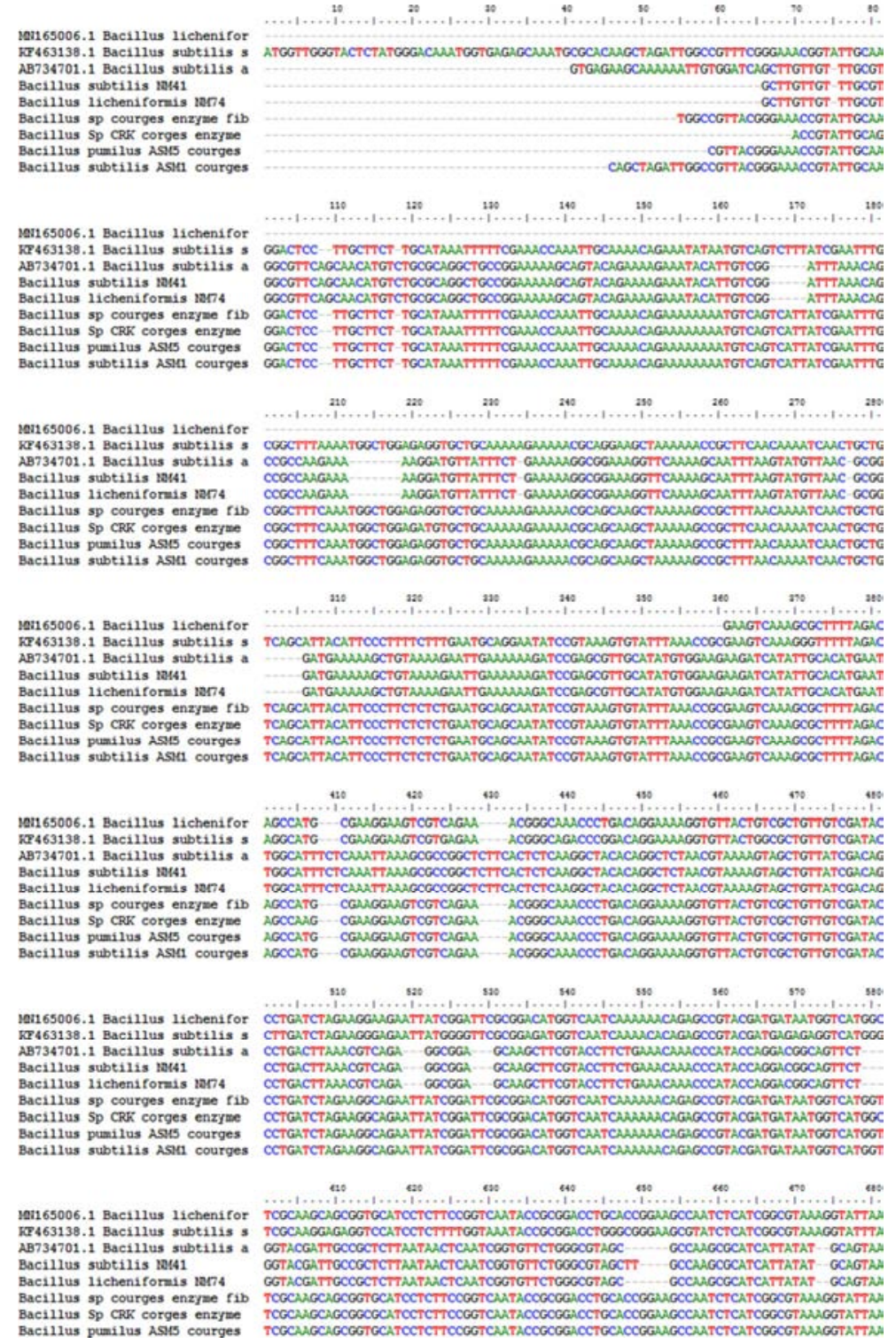

Figure 3. Part of the alignment of the nucleotide sequences of the genes encoding the fibrinolytic enzymes of squash strains and their homologs. 


\subsubsection{Protein Sequence Analysis}

From the nucleotide sequences of the genes coding for fibrinolytic enzymes in pumpkin strains, we did the translation and the protein sequences obtained were analyzed by a Blastp.

Table 1 shows that all these proteins act as acid.

Table 1. The different properties of the four fibrinolytic proteases elaborated from bacteria isolated from squashes.

\begin{tabular}{lllllll}
\hline $\begin{array}{l}\text { Fibrinolytic } \\
\text { Proteases }\end{array}$ & Protein GRAVY & Isoelectric point & Molecular weight & $\begin{array}{l}\text { Amino acid } \\
\text { residus }\end{array}$ & $\begin{array}{l}\text { GenBank accession numbers } \\
\text { of related genes }\end{array}$ & Protein ID \\
\hline CFE1 & -0.297 & $\mathrm{pH} 4.48$ & $38.94 \mathrm{kDa}$ & 366 & MT743004 & QNJ60181.1 \\
CFE2 & -0.342 & $\mathrm{pH} 4.46$ & $40.47 \mathrm{kDa}$ & 380 & MT743005 & QNJ60182.1 \\
CFE3 & -0.291 & $\mathrm{pH} 4.57$ & $26.16 \mathrm{kDa}$ & 244 & MT743006 & QNJ60183.1 \\
CFE4 & -0.361 & $\mathrm{pH} 4.43$ & $40.38 \mathrm{kD}$ & 379 & MT743007 & QNJ60184.1 \\
\hline
\end{tabular}

Table 2 shows the similarity levels of each protein to the homologous sequences in the NR library using Blastp-NCBI. The level of identity for all proteins is greater than $99.50 \%$, allowing them to be identified as belonging to the AprX [Bacillus] family of serine proteases. These form a very broad group among fibrinolytic enzymes.

Table 2. Results of bioinformatics analyses on BLASTp of the genes encoding the fibrinolytic enzymes of the four (4) squash strains.

\begin{tabular}{llllllll}
\hline Strains & $\begin{array}{l}\text { Max } \\
\text { score }\end{array}$ & $\begin{array}{l}\text { Total } \\
\text { score }\end{array}$ & $\begin{array}{l}\text { Query } \\
\text { cover }\end{array}$ & $\begin{array}{l}\text { E. } \\
\text { value }\end{array}$ & $\begin{array}{l}\text { Percentage } \\
\text { of similarity }\end{array}$ & Type of enzyme & $\begin{array}{l}\text { Accession Numbers of } \\
\text { equivalent strains in GenBank }\end{array}$ \\
\hline Bacillus subtilis ASM1 & 851 & 851 & $98 \%$ & 0.0 & $99.51 \%$ & Multispecies: serine protease AprX [Bacillus] & WP_041850809.1 \\
Bacillus pumilusASM5 & 568 & 568 & $100 \%$ & 0.0 & $99.63 \%$ & serine protease AprX [Bacillus] & WP_024572446.1 \\
Bacillus sp ASM7 & 844 & 844 & $100 \%$ & 0.0 & $99.75 \%$ & serine protease AprX [Bacillus] & WP_041336030.1 \\
Bacillus sp CRK & 848 & 848 & $100 \%$ & 0.0 & $99.76 \%$ & serine protease AprX [Bacillus] & WP_041336030.1 \\
\hline
\end{tabular}

\subsubsection{Sequences Alignment of Fibrinolytic Proteases}

Figure 4 show the amino acid alignment,

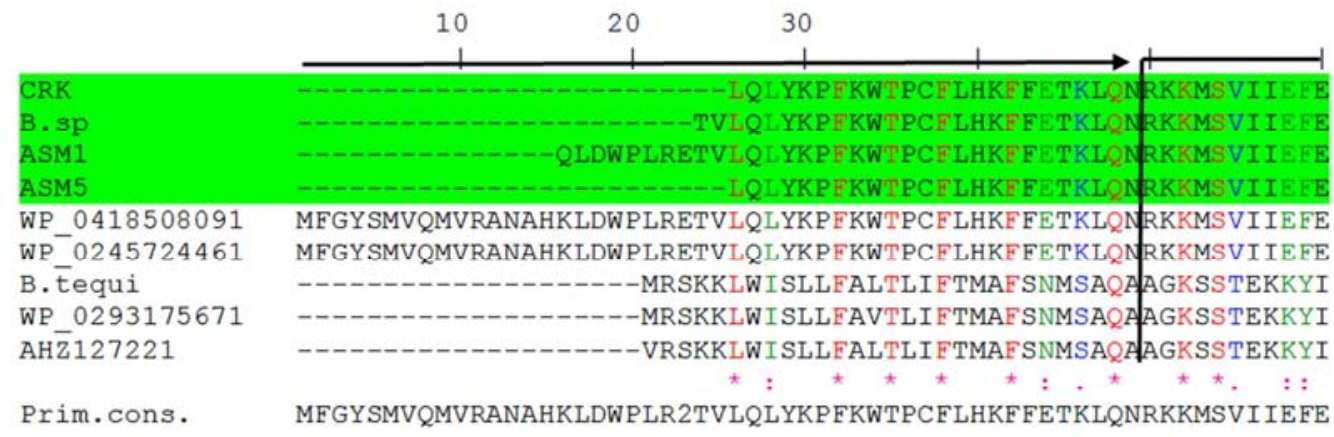

\begin{tabular}{|c|c|c|}
\hline & Pro-Peptide & 110 \\
\hline ERK & GFQMAGDVLQ---KEKRSKLKSRFNKINS & VTPSALHSLLSECSNIRKVYL \\
\hline B.sp & GFQMAGDVLQ---KEKRSKLKSRENKINCCSAEV & VTPSALHSLLSECSNIRKVYL \\
\hline ASM1 & GCHET GFQMAGEVLQ---KEKRSKLKSRFNKINCCSAEV & VTPSALHSLLSECSNIRKVYL \\
\hline ASM5 & EGCHETGFQMAGEVLQ---KEKRSKLKSRFNKINCCSAEV & VTPSALHSLLSECSNIRKVYL \\
\hline WP_0418508091 & EGCHETGFQMAGEVLQ---KEKRSKLKSRFNKINCCSAEV & VTPSALHSLLSECSNIRKVYL \\
\hline WP_0245724461 & EGCHETGFQMAGEVLQ---KEKRSKLKSRFNKINCCSAEV & VTPSALHSLLSECSNIRKVYL \\
\hline B. tequi & VGFKQTMSAMSSAKKKDVISEKGGKVQKQFKYVNAAAATI & LDEKAVKELKKDPSVAYVEED \\
\hline 5671 & VGFKQTMSAMSSAKKKDVISEKGGKVQKQEKYVNAAAATI & LDEKAVKELKKDPSVAYVEED \\
\hline AHz̄ 127221 & 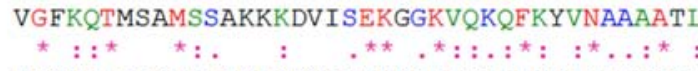 & $\begin{array}{l}\text { LDEKAVKELKKDPSVAYVEED } \\
: \quad \cdot^{*}::^{*} \cdot:^{*}\end{array}$ \\
\hline lm.cons. & QMAGEVLQDVIKEKRSKLKSRFNKINCCSAEV & VTPSALHSLLSECSNIRK \\
\hline
\end{tabular}

\begin{tabular}{|c|c|c|c|c|c|}
\hline Pro & eptide & Peptide mature & & 160 & 180 \\
\hline CRK & NREVKA & ELDTATEASQAKEVVRNGQTLTG & SKGVTV? & GIYP-HPDLEG & GRIIGFADMVN \\
\hline B.sp & NREVKA & LLDTATEASQAKEVVRNGQTLTG & SKGVTVAV & FGIYP-HPDLEG & GRIIGFADMVN \\
\hline ASM1 & NREVKA & ELDTATEASHAKEVVRNGQTLTG & GKGVTVAV & FGIYP-HPDLEG & GRIIGFADMVN \\
\hline ASM5 & NREVKA & LLDTATEASHAKEVVRNGQTLTG & JKGVTVAV & FIYP-HPDLEG & GRIIGFADMVN \\
\hline WP 0418508091 & NREVKA & ELDTATEASHAKEVVRNGQTLTG & EKGVTVAVY & ATGIYP-HPDLEG & GRIIGFADMVN \\
\hline WP 0245724461 & NREVKA & ELDTATEASHAKEVVRNGQTLTG & GKGVTVAVV & ITIYP-HPDLEG & GRI I GFADMVN \\
\hline B. tequi & HIAHEY & AQSVPYGISQIKAPALHSQGYTG & GSNVKVAVI & IASGIDSSHPDLN- & --VRGGASFVP \\
\hline WP_0293175671 & HIAHEY & QSVPYGISQIKAPALHSQGYTG & GSNVKVAVI & IDSGIDSSHPDLN- & --VRGGASFVP \\
\hline
\end{tabular}


AHZ127221

HIAHEYAOSVPYGISOIKAPALHSOGYTGSNVKVAVIDSGIDSSHPDLN--VRGGASFVP

Prim.cons. NREVKALLDTATEASQAKEVVRNGQTLTGKGVTVAVVDTGIYPSHPDLEGRI I GFADMVN

\begin{tabular}{|c|c|c|}
\hline CRK & QKTEPYDD-NG & FTHCAGDVASSGASSSGQYRGPAPEANLIGVKVLNKQGSGTLADI IEG \\
\hline B.sp & & FTHCAGDVASSGASSSGQYRGPAPEANLIGVKVLNKQ̈GSGTLADI IEG \\
\hline ASM1 & QKTEPYDD-NC & FTHCAGDVASSGASSSGQYRGPAPEANLIGVKVLNKQ̈GSGTLADI IEG \\
\hline ASM5 & QKTEPYDD-NC & FTHCAGDVASSGASSSGQYRGPAPEANLIGVKVLNKQGSGTLADIIEG \\
\hline WP_0418508091 & QKTEPYDD-NC & FTHCAGDVASSGASSSGQYRGPAPEANLIGVKVLNKQGSGTLADI IEG \\
\hline WP_-0245724461 & & FTHCAGDVASSGASSSGQYRGPAPEANLIGVKVLNKQGSGTLAD \\
\hline B. taqui & SET: & FTHVAGTIAALNNS IG--VLGVAPSASLYAVKVLDSTGSGQYSWI ING \\
\hline WP_0293175671 & SETNPYQDGSAH & FTHVAGT IAALNNS IG--VLGVAPSASLYAVKVLDSTGSGQYSWI ING \\
\hline $\mathrm{AHz} 127221$ & $\begin{array}{l}\text { SETNPYQDGSH } \\
.:^{\star}: \star \star: \star \ldots\end{array}$ & 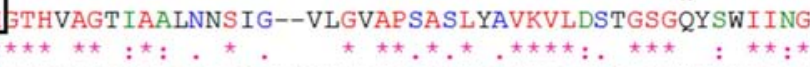 \\
\hline ns & & GTHCAGDVASSGASSSGQYRGPAPEANLIGVKVLNKQGSGTLADI IEG \\
\hline
\end{tabular}

Prim.cons.

250

260

Peptide mature

280

290

300

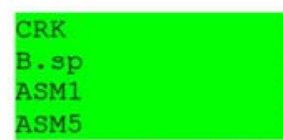

VEWCIQYNEDNPDEPIDIISMSLGGDALRYDHEQEDPLVRAVEEAWSAGIVVCVAAGNSG VEWCIQYNEDNPDEPIDI ISMSLGGDALRYDHEQEDPLVRAVEEAWSAGIVVCVAAGNSG VEWCIQYNEDNPDEPIDIISMSLGGDALRYDHEQEDPLVRAVEEAWSAGIVVCVAAGNSG VEWCIQYNEDNPDEPIDI ISMSLGGDALRYDHEQEDPLVRAVEEAWSAGIVVCVAAGNSA

WP 0418508091

VEWCIQYNEDNPDEPIDI ISMSLGGDALRYDHEQEDPLVRAVEEAWNAGIVVCVAAGNSG WP 0245724461

B. tequi

VEWCIQYNEDNPDEPIDI ISMSLGGDALRYDHEQEDPLVRAVEEAWSAGIVVCVAAGNSG IEWAISNN------MDVINMSLGGPTG-----STALKTVVDKAVSSGIVVAAAAGNEG

WP 0293175671

IEWAISNN------MDVINMSLGGPSG-----STALKTVVDKAVSSGIVVAAAAGNEG

$\mathrm{AH} \overline{\mathrm{z}} 127221$

IEWAISNN------MDVINMSLGGPSG------STALKTVVDKAVSSGIVVAAAAGNEG

Prim.cons.

VEWCIQYNEDNPDEPIDI ISMSLGGDALRYDHEQEDPLVRAVEEAWSAGIVVCVAAGNSG

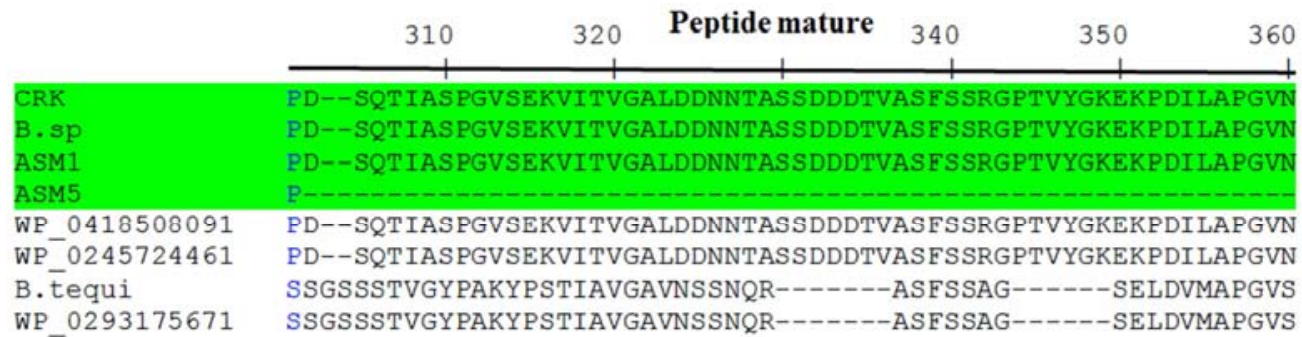

AHZ127221

SSGSSSTVGYPAKYPSTIAVGAVNSSNQR

SELDVMAPGVS

370

IISLRSPNSYIDKLQKSSRV IISLRSPNSYIDKLQKSSRV IISLRSPNSYIDKLQKSSRVC

B.sp

ASM5

WP 0418508091

WP-0245724461

B. sp

WP_0293175671

AHz̄ 127221

Prim.cons.
I ISLRSPNSYIDKLQKSSRV S SYFTMSGTSMATPICAGIAALILQQNPDLT PDEVKELL I ISLRS PNSY IDKLQKSSRV S SYFTMSGT SMAT PICAGIAAL I LQQNPDLT PDEVKELI

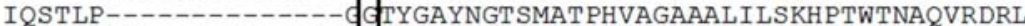
IQSTLP----------d ITYGAYNGTSMATPHVAGAAALILSKHPTWTNAQVRDRL

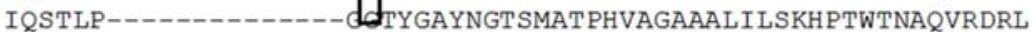

I ISLRSPNSYIDKLQKSSRVGSQYFTMSGTSMATPICAGIAALILQ2NPDLTPDEVKELL

\begin{tabular}{ll}
\multicolumn{2}{c}{ Peptide mature 30} \\
\cline { 2 - 3 } CRK & KNGTDKWKDEDPNVYGAGS- \\
B.sp & KNGTDKWKDEDPNVYGAGS \\
ASM1 & KNGTDKWKDEDPNIYGTGAVNAENSVPGQ \\
ASM5 & KNGTDKWKDEDPNVYGAGAVNAENSVPGQ \\
WP_0418508091 & \\
WP_0245724461 & ESTATYLG--NSFYYGKGLINVQAAAQ-- \\
B.tequi & ESTATYLG--NSFYYGKGLINVQAAAQ-- \\
WP_0293175671 & \\
AHZ127221 & ESTATYLG--NSFYYGKGLINVQAAAQ-- \\
Prim.cons. & KNGTDKWKDEDPN2YGAGLINVQAAAQGQ
\end{tabular}

Figure 4. Alignment of amino acid sequences of fibrinolytic enzymes in four (4) Bacillus strains isolated from squashes. 
These genes have been structured in three (3) parts: a first part called a signal peptide whose number of amino acid residues varies from one strain to another. In Bacillus sp CRK and ASM5 strains, the signal peptide contains 24 amino acids, 26 in B.sp ASM7 and finally 33 amino acid residues for Bacillus subtilis ASM1, a second part called pro-peptide contains about 74 amino acids and finally a third part called mature peptide which contains 310 amino acid residues.

\subsubsection{Phylogenetic Classification Based on Protein Sequences}

Figure 5 shows the phylogenetic relationship between the fibrinolytic enzymes produced by strains of the genus Bacillus isolated from red-coloured squash and some related homologues. The arrangement of the branches clearly shows that all four enzymes have the same common ancestor and are grouped together thus sharing the same node.

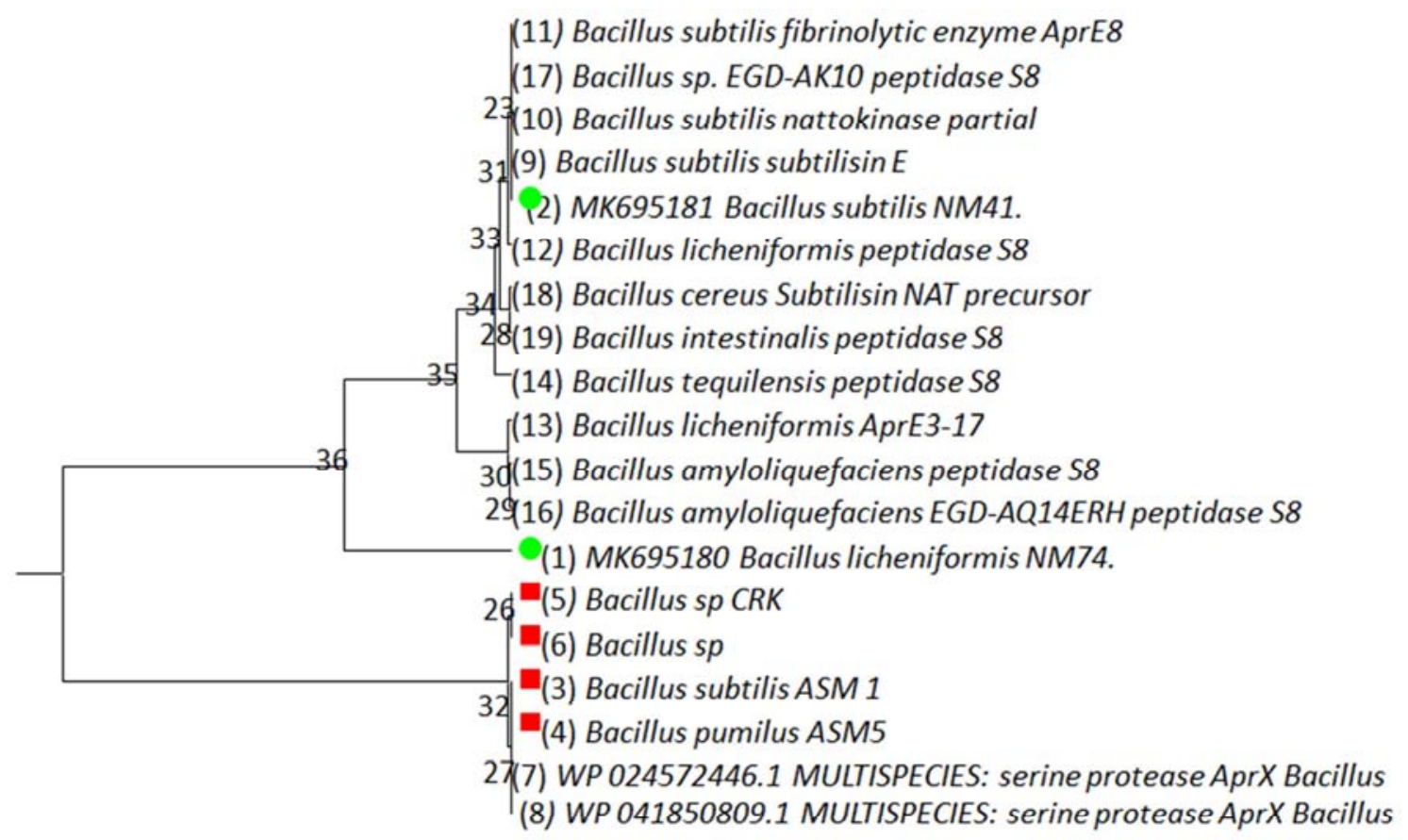

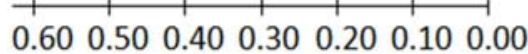

Figure 5. Phylogenetic tree made from the amino acid sequences of fibrinolytic enzymes.

The evolutionary history was deduced using the maximum likelihood method based on the JTT matrix model. The tree with the highest log probability (-1508.56) is displayed. The initial trees for the heuristic search were obtained automatically by applying the neighborhoods and join algorithms to a matrix of paired distances estimated using a JTT model, and then selecting the topology with a higher log likelihood value. The tree is drawn to scale, with branch lengths measured in the number of substitutions per site (next to the branches). The analysis involved 19 amino acid sequences. All positions containing gaps and missing data were eliminated. There were a total of 182 positions in the final data set. Evolutionary analyses were performed in MEGA7 [25].

\section{Discussion}

It is important to note the presence of proteolytic activity in squash bacteria. In addition, 4 isolates showed fibrinolytic activity (Figure 1). The genus Bacillus is recognized among bacteria that secrete bioactive substances such as proteases and bacteriocins $[26,27,14,28]$.
The protein sequences of the fibrinolytic enzymes in strains isolated from squash were aligned Figure 4. These sequences were compared with those of other serine proteases with similarity rates (Table 2) ranging from $99.51 \%$ to $99.76 \%$. Analysis of the pre-peptide part of these four (4) enzymes clearly shows a difference. For the CRK and ASM5 strains, the first amino acid is a leucine, whereas in $B . S p$ it starts with a threonine and in ASM1 it is glutamine which is the first amino acid, whereas in the two (2) homologues the pre-peptide starts with a methionine $[29,30]$. Considering the mature peptide, the first 11 amino acids of the four (4) fibrinolytic enzymes are respectively LLDTATEASQI. This part is very similar to the two (2) homologues of the same gene type (serine protease AprX Bacillus) which are reference genes [30] but differs from those of subtilisin DFE found in Bacillus amyloliquefaciens $C D$ 4 [31], \& and subtilisin BSF1 found in Bacillus subtilis A26 [32] where the first 8 amino acids in subtilisin $E$ (AQSVPYGVSQIKA) Ala1, Gln2, Ser3, val4, Pro5, Tyr6, Gly7, Val8, have been replaced by Leu1, Leu2, Asp3, Thr4, Ala5, Thr6, Glu7, Ala8 in the fibrinolytic enzymes produced by Bacillus bacteria isolated from squashes. In addition, the 
catalytic triad consisting of Ser, His and Asp of the four (4) enzymes is preserved. These results are similar to those published by $[33,32]$. The four fibrinolytic proteases of the bacterial strains isolated from squashes were recorded in the databases and the Id are recorded in Table 1. All these proteases have very similar characteristics.

Analysis of phylogenetic inference based on fibrinolytic protease sequences indicates that two proteases developed by Bacillus subtilis MN41 and Bacillus licheniformis MN74 homologues [21] are also in the same group (serine protease AprX Bacillus). These two proteases, whose N-terminal end is different from the four proteases developed by the Bacillus isolated from squashes in this study, are all in the same phylogeny. All of this supports the hypothesis that since LUCA and over the course of evolution all these fibrinolytic proteases have evolved in the same family, the mutations have not affected the active site whose catalytic triad is always Ser-His-Asp.

All the fibrinolytic proteases CFE1 (Id=QNJ60181) for Bacillus sp strain ASM7, the CFE2 (Id=QNJ60182) for Bacillus sp strain CRK, CFE3 (Id=QNJ60183) for Bacillus pumilus strain ASM5, CFE4 (Id=QNJ60184) for Bacillus subtilis strain ASM1 are AprX serine protease. All of them display closely related biochemical properties in concordance with their roles.

\section{Conclusion}

At the end of this study, it should be said that the four (4) Bacillus strains isolated from squashes are very promising. The fibrinolytic activity assay has shown that these strains produce fibrinolytic enzymes. Furthermore, amplification by PCR and bioinformatics analysis of these genes has enabled them to be characterized. The four (4) enzymes belong to the family of serine proteases of the Apr type. These four fibrinolytic proteases have been registered in the databases and have an identifier for each one, they display closely related biochemical properties in concordance with their roles. This study has confirmed the use of fibrinolytic enzymes in Bacillus strains as phylogenetic molecular markers.

\section{Conflict of Interest}

Authors declare no conflict of interest.

\section{Acknowledgements}

We are grateful to professor Joseph GOMATCHIMBAKALA, General Director of Institute of Research in Exact and Natural Sciences (IRSEN), for providing laboratory material. Docteur Mireille BELLE MBOU for managing the gene sequencing.

\section{References}

[1] Gupta, R., Beg, Q., Lorenz, P. (2002). Bacterial alkaline proteases: molecular approaches and industrial applications. Applied Microbiology and Biotechnology, 59: 15-32.
[2] Chang, C, T., Wang, P, M., Hung, Y, F., Chung, Y, C. (2012): Purification and biochemical properties of a fibrinolytic enzyme from Bacillus subtilis-fermented red bean. Food Chemistry, Volume 133, Issue 4, 15 August 2012, Pages 1611-1617.

[3] Jeong, Y, K. Park, J, U., Baek, H., Park, S, H., Kong, I, S., Kim, D, W., Joo, W, H. (2001) Purification and biochemical characterization of a fibrinolytic enzyme from Bacillus subtilis BK-17. World J Microbiol Biotechnol 17: 89-92.

[4] Kim, W., Choi, K., Kim, Y., Park, H., Choi, J., Lee, Y., Lee, S. (1996). Purification and Characterization of a Fibrinolytic Enzyme Produced from Bacillus sp. strain CK 11-4 Screened from Chungkook-Jang, Applied and Environmental $\begin{array}{llll}\text { Microbiology, } & 62 & \text { (7), } & \text { 2482-2488. }\end{array}$ 10.1128/AEM.62.7.2482-2488.1996.

[5] Bijender, K, B., Satbir, S., Mowkshi, K., Kaurab, S., Shikha, B. (2014): Optimization of Fibrinolytic Protease Production from Bacillus subtilis I-2 Using Agro-Residues. Braz. Arch. Biol. Technol. v. 57 n. 5: pp. 653-662.

[6] Chang, C., Wang, P., Hung, Y., Chung, Y. (2012). Purification and biochemical properties of a fibrinolytic enzyme from Bacillus subtilis -fermented red bean. Food Chemistry, 133 (4), 1611-1617.

[7] Kim, H., Kim G., Kim D. (1997). Purification et caractérisation d'une nouvelle enzyme fibrinolytique du Bacillus sp. KA38 originaire de poisson fermenté. $J$. Fermenter. Bioeng, 84. 307-312.

[8] Sherry. S (1987). Appraisal of various thrombolytic agents in the treatment of acute yocardial infarction The American Journal of Medicine Volume 83, Issue 2, Supplement 1, Pages https://doi.org/10.1016/0002-9343(87)90885-0.

[9] Wang, C. T., Ji, B. P., Li, B., Nout, R., Li, P. L., Ji, H., Chen, L, F. (2006). Purification and characterization of a fibrinolytic enzyme of Bacillus subtilis DC33, isolated from Chinese traditional Douchi. The Journal of Industrial Microbiology and Biotechnology, 33 (9), 750-758. Sumi, H., Hamada, H., Tsushima, H. (1987). A novel fibrinolytic enzyme (nattokinase) in the vegetable cheese Natto: A typical and popular soybean food in the Japanese diet, Experientia 43 (1987) 1110-1111.

[10] Sumi, H., Nakajima, N., C. Yatagai, A. (1995). Unique strong fibrinolytic enzyme (Katsuwokinase) in skipjack "shiokara", a Japanese traditional fermented food, Biochem. Mol. Biol. 112 543-547.

[11] Kim, S, H., Choi, N, S. (2000). Purification and characterization of subtilisin DJ-4 secreted by Bacillus $s p$ strain DJ-4 screened from Doen-Jang. Biosci Biotechnol Biochem 64: 1722-1725.

[12] Wong, A, H, K., Mine Y. (2004). Novel fibrinolytic enzyme in fermented shrimp paste, a traditional Asian fermented seasoning. $J$ Agr Food Chem. 52, 980-986, https://doi.org/10.1021/jf034535y.

[13] Kim, S, B., Lee D, W., Cheigh, C, I., Choe, E, A., Lee, S, J., Hong, Y, H., Choi, H, J., Pyun, Y, R. (2006): Purification and characterization of a fibrinolytic subtilisin-like protease of Bacillus subtilis TP-6 from an Indonesian fermented soybean, Tempeh. $J$ Ind Microbiol Biotechnol; 33: 436-44. 
[14] Nguimbi, E., Ahombo, G., Moyen, R., Ampa, R., Vouidibio, A., Nina, E.,... Louembe, D. (2014). Optimization of Growth, Fibrinolytic Enzyme Production and PCR Amplification of Encoding Fibrinolytic Enzyme Gene in Bacillus amyloliquefaciens Isolated from Ntoba mbodi at Brazzaville, International Journal of Science and Research (IJSR), 3 (11), 2799-2803.

[15] Hu, Y., Yu, D., Zhaoting, W., Hou, J., Tyagi, R., Liang, Y. (2019). Purification and characterization of a novel, highly potent fibrinolytic enzyme from Bacillus subtilis DC27 screened from Douchi, a traditional Chinese fermented soybean food, Scientific Reports 2019, N 1, (May), 3-12.

[16] Soloka, M, F, A., Nguimbi, E., Kayath, A, C., Ahombo, G. (2020) Molecular characterization of Bacilllus-genus Bacteria with Fibrinolytique isolated from squashes $<<$ NTETE $\geq \geq$ in the Brazzaville in the republic Of Congo. American journal of Microbiological Research, Vol 8. No. 1, 7-18.

[17] Lagzouli, M., Charouf, R., Yachioui, El, M., Ouhssine, M, Berny, El, H., Jadal, M. (2007). Optimisation de la croissance glucoamylase extracellulaire, Bull. Soc. Pharm. Bordeaux 146, 251-270.

[18] Soloka, M, F, A., Moyen, R., Nguimbi, E., Gabriel Ahombo., Raoul Ampa., Kayath, A, C., Vouidibio, A., Morabandza, C, J., Kobawila S, C. (2017) Production, Partial Purification and Based SDS-PAGE profiles of Caseinolytic Enzyme in two Bacillus strains isolated from fermented cassava leaves "ntoba mbodi" in congo Brazzaville. Journal of pure and applied microbiology, vol. 11 (1), p. 77-86.

[19] Wang, S, H., Zhang, C., Yang, Y, L, Diao, M., Bai, M, F. (2007). Projection de haute enzyme fibrinolytique production souche et la caractérisation de l'enzyme fibrinolytique produite à partir de Bacillus subtilis LD 8547. J. mondiale Microbiol. Biotechnol, 7. Epub.

[20] Kotb, E. (2015). Purification and partial characterization of serine fibrinolytic enzyme from Bacillus megaterium KSK-07 isolated from Kishk, a traditional egyptian fermented food. Appl Biochem Micro. 51, 34-43, https://doi.org/10.1134/s000368381501007x.

[21] Soloka, M, F, A., Nguimbi, E., Ampa, R.,; Kayath, A, C., Vouidibio, A., Ahombo, G. (2018). Production, Encoding Genes Variability and N- Terminal Sequences of Fibrinolytic Enzymes Produced by Bacillus Strains Isolated from Fermented Cassava Leaves " Ntoba Mbodi " at Brazzaville, Republic of Congo' International Journal of Science and Research (IJSR) 7, 241-48.

[22] Mir M, S., H., Rabbani M., Naghitorabi, M. (2009): Cloning of alkaline protease gene from Bacillus subtilis 168 Research in Pharmaceutical Sciences, 4 (1): 43-46.

[23] Altschu, F, S., Gish, W., Miller, W., Myers, W. E., Lipman, J, D (1990): Basic Local Alignement search Tool. J. Mol. Biol. $215403-410$.
[24] Rouhou, C. (2006). Evaluation des classifications phylogénétiques des bacillaceae basées sur les gènes de l'opéron rrn et de gènes de ménage. Memoire pour l'obtention de la maîtrise en biologie.

[25] Kumar, S., Stecher G., Tamura, K. (2016). MEGA7: Molecular Evolutionary Genetics Analysis version 7.0 for bigger datasets. Molecular Biology and Evolution 33: 18701874 .

[26] Barboza-Corona, J, E., De la Fuente-Salcido, N., Alva-Murillo N., Ochoa-Zarzosa A., LopezMeza, J, E. (2009). Activity of bacteriocins synthesized by Bacillus thuringiensis against Staphylococcus aureus isolates associated to bovine mastitis. Veterinary Microbiology 138, $\mathrm{n}^{\circ}$ 1: 179-183.

[27] Pacheco Cano, R, d., Norm, M., De la Fuente-Salcido., Salcedo-Hermandez, R., José E. Barboza, C., HernandezGuzman G., Leon-Galvan, M, F., Bideshi, D, K. (2014). Characterization, N-terminal sequencing and classification of Tolworthcin 524: a bacteriocin produced by Bacillus thuringiensis subsp. tolworthi. Microbiological research 169: 948-953.

[28] Mokemiabeka, N, S., Kayath, C, A., Nguimbi, E., Augustin, A., Guy, A., Eboungabeka, M., Botteaux, A. (2016). Microbiological and biochemical assessment of crushed red pepper from Capsicum frutescens preserved in jars and manufactured in local markets in Republic of Congo, International Journal of Biotechnology Research 4 (October), $1-10$.

[29] Heo, K., Cho, K. M., Lee, C. K., Kim, G. M., Shin, J., Kim, J. S., \& Kim, J. H. (2013). Characterization of a Fibrinolytic Enzyme Secreted by Bacillus amyloliquefaciens CB1 and Its Gene Cloning. J. Microbiol. Biotechnol. (2013), 23 (7), 97498323 (7), 974-983.

[30] Kodama, T., Endo, K., Sawada, K., Ara, K., Ozaki, K., Kakeshita, H., Sekiguchi, J. (2007). Bacillus subtilis AprX Involved in Degradation of a Heterologous Protein During the Late Stationary Growth Phase, Journal of bi osci ence and bi oengi ne ering 104 (2), 135-143.

[31] Peng, Y., Yang, X., Xiao, L., \& Zhang, Y. (2004). Cloning and expression of a fibrinolytic enzyme (subtilisin DFE) gene from Bacillus amyloliquefaciens DC-4 in Bacillus subtilis, Research in Microbiology 155 155, 167-173.

[32] Agrebi, R., Haddar, A., Hmidet, N., Jellouli, K., Manni, L., Nasri, M. (2009). BSF1 fibrinolytic enzyme from a marine bacterium Bacillus subtilis A26: Purification, biochemical and molecular characterization, Process Biochemistry journal 44: $1252-1259$ 